\title{
PENGEMBANGAN PERANGKAT PEMBELAJARAN KOOPERATIF TIPE STAD DENGAN PENILAIAN PORTOFOLIO PADA PEMBELAJARAN MATEMATIKA BERORIENTASI KEMAMPUAN AWAL
}

\author{
Intan Sari Rufiana ${ }^{1}$ Mardiyana $^{2}$, dan Gatut Iswahyudi ${ }^{3}$ \\ ${ }^{1,2,3}$ Prodi Magister Pendidikan Matematika, PPs Universitas Sebelas Maret Surakarta
}

\begin{abstract}
The aims of this study were to: (1) produce a learning device in STAD cooperative learning model with a portfolio that was good for the subject of algebra in seventh grade junior high school, (2) know the effectiveness of cooperative learning of STAD type with portfolio assessment when it is viewed from early ability. This research was a kind of research and development. The development procedure used in this study was the development of a learning device according Thiagarajan et al, which was consisted of four stages: define, design, development, and disseminate. In disseminate stage, the experiment was conducted with portfolio assessment. Experiments conducted on the two junior high schools, they were Muhammadiyah Yanggong junior high school and Muhammadiyah Jenangan junior high school. Based on the inferential analysis, it showed that (1) the learning outcomes of students who were taught mathematics STAD cooperative learning with portfolio assessment was better than the mathematics learning outcomes of students who were taught STAD cooperative learning on the subject of algebra, (2) students who had high early ability had better performance than who had low early ability, (3) in the high ability, the students who were taught by using STAD cooperative learning model with portfolio assessment had better learning achievement than the students who were taught by using STAD cooperative model STAD without portfolio assessment, (4) in the low early ability, the students who were taught using STAD cooperative learning model with portfolio assessment had the same performance with STAD cooperative learning model without portfolio assessment, (5) the students who were taught by the STAD cooperative learning without portfolio assessment, students who had high early ability had better performance than who had low early ability, and (6) the students who were taught by using STAD cooperative learning model with portfolio assessment, the students who had high early ability had better performance than the students who had early ability.
\end{abstract}

Key words: Cooperative STAD, Portfolio Assessment, Early ability

\section{PENDAHULUAN}

Peranan dan kompetensi guru dalam proses pembelajaran meliputi banyak hal sebagaimana yang dikemukakan oleh Deckey and Adam (1995) dalam Basic Principles of Student Teaching, antara lain guru sebagai pengajar, pemimpin kelas, pembimbing, pengatur lingkungan, partisipan, perencana, motivator, dan konselor. Namun kenyataan menunjukkan bahwa profesional guru Indonesia belum sesuai dengan yang diharapkan. Hal ini dikarenakan adanya berbagai kendala baik personal, sosial, struktural maupun kultural. Menurut Balitbang Depdiknas dalam Hafis (2011) bahwa persentase guru menurut kelayakan mengajar dalam tahun 2010 - 2011 di berbagai satuan pendidikan sebagai berikut: untuk SD yang layak mengajar 26.83\% (negeri) dan 28.94\% (swasta), 
untuk SMP 54.12\% (negeri) dan 60.99\% (swasta), untuk SMA 65.29\% (negeri) dan 64.73\% (swasta), untuk SMK 55.91\% (negeri) dan 58.26\% (swasta).

Guru dikatakan sebagai pekerja profesional jika menguasai empat kompetensi dengan baik (Burhanudin Tola dan Fahmi:2003). Empat kompetensi itu adalah : (1) Menguasai substansi, (2) Menguasai metodologi mengajar, (3) Menguasai teknik evaluasi yang baik, (4) Memahami, menghayati, dan mengamalkan nilai-nilai moral dan kode etik profesi. Dari keempat kompetensi itu yang paling utama harus dikuasai oleh seorang guru adalah tentang penguasaan metodologi mengajar dan penggunaan alat penilaian karena berkaitan langsung dengan interaksi siswa dan guru dalam pembelajaran.

Sebagian besar atau bahkan semua guru mengetahui dalam pembelajaran perlu dilakukan penilaian proses di samping penilaian hasil. Namun pada kenyataannya, sebagian guru ada yang kurang memperdulikan dan tidak melakukan penilaian proses, mereka lebih mementingkan hasil belajar siswa pada akhir semester, akhir tahun, atau ujian akhir. Hal ini terjadi karena sistem penilaian yang terjadi saat ini lebih mengandalkan atau mempercayai hasil akhir dari pada proses belajar siswa. Dengan demikian terjadilah istilah teaching to the test (Popham:2001), yaitu guru lebih banyak memberikan cara praktis penyelesaian soal dari pada bersusah payah menerangkan atau membahas teori, walaupun sebenarnya hal itu dapat mengakibatkan siswa tidak mendapatkan pengalaman belajar yang optimal. Dengan pengertian lain, guru mengajar dan siswa belajar semata-mata untuk ujian saja.

Observasi di lapangan mendukung hal tersebut di atas, misalnya di beberapa SMP Muhammadiyah di Ponorogo. Berdasarkan hasil wawancara peneliti dengan guruguru di sekolah-sekolah tersebut, penilaian yang dilakukan hanya penilaian akhir yaitu ulangan kompetensi dasar, UTS, dan UAS tanpa disertai penilaian proses. Berdasarkan observasi yang dilakukan peneliti, situasi proses pembelajaran adalah sebagai berikut: keseriusan siswa terlihat hanya saat ada ulangan saja, banyak di antara mereka yang mengaku belajar hanya pada saat akan diadakan ulangan. Tidak jarang dari mereka menghalalkan segala cara yang tidak baik untuk mencapai nilai ujian yang optimal, seperti membuka buku untuk mencontek ataupun bekerja sama dengan temannya. Hal ini menyebabkan guru sendiri sulit membedakan kemampuan siswa satu dengan lainnya, karena hasil nilai dari ulangan kompetensi dasar, UTS, dan UAS cenderung sama siswa satu dengan lainnya. Selain itu, guru juga tidak memberikan balikan kepada siswa, guru hanya memberikan remidi atau ulangan kembali dengan soal yang sama kepada siswa yang nilainya kurang dari standar ketuntasan minimal kelas.

Peneliti juga melakukan wawancara dengan guru mengenai metode pembelajaran yang digunakan. Dari hasil wawancara diketahui bahwa sudah sering digunakan 
pembelajaran dengan berkelompok, tetapi guru merasakan bahwa hasil yang didapat belum optimal. Hal ini terlihat dari kerja kelompok hanya dikuasasi oleh siswa kelompok pandai saja, kelompok tidak pandai cenderung malas mengerjakan soal-soal yang diberikan guru. Hal tersebut di atas terjadi karena belum adanya perangkat pembelajaran yang sesuai dengan pembelajaran kelompok. Oleh karena itu, peneliti merasa tertarik untuk mengembangkan perangkat pembelajaran yang digunakan. Diharapkan dengan perangkat pembelajaran itu, pengorganisasian kelompok pada pembelajaran, khususnya pada jam-jam akhir akan lebih optimal. Perangkat pembelajaran yang dikembangkan adalah perangkat pembelajaran model kooperatif tipe STAD dengan penilaian portofolio.

Irma Pujianti (2008) menjelaskan bahwa STAD (Student Teams Achievement Divisions) merupakan salah satu pendekatan dalam pembelajaran kooperatif yang paling sederhana, yang dikembangkan oleh Robert Slavin di Universitas John Hopkin. Slavin (1992) menjelaskan bahwa STAD terdiri atas lima komponen utama yaitu: presentasi kelas, tim, kuis, skor kemajuan individual dan rekognisi tim. Dalam model pembelajaran kooperatif tipe STAD, kemampuan awal siswa memiliki peranan yang sangat penting. Dengan mengetahui kemampuan awal, guru dapat memberikan skor kemajuan individual dan membagi siswa menjadi beberapa kelompok dengan tingkat kemampuan awal tinggi dan rendah. Siswa yang memiliki kemampuan awal tinggi mungkin tidak akan mengalami kesulitan dalam memahami materi sehingga memiliki prestasi belajar matematika yang lebih baik. Sebaiknya bagi siswa yang memiliki kemampuan awal rendah mungkin mengalami banyak kesulitan dalam memahami materi sehingga mengakibatkan rendahnya prestasi belajar matematika siswa.

Menurut Sumarna Supranata dan Muhammad Hatta (2004) portofolio dapat diartikan sebagai kumpulan hasil evidence atau hasil belajar atau karya siswa yang menunjukkan usaha, perkembangan, prestasi belajar siswa dari waktu ke waktu. Portofolio sangat berpengaruh sebagai alat untuk meningkatkan pendidikan yang memungkinkan siswa untuk lebih berpartisipasi dalam proses pembelajaran. Digunakannya penilaian portofolio adalah karena seharusnya guru menggunakan penilaian untuk mengumpulkan informasi sebanyak-banyaknya tentang kemampuan belajar siswanya. Jadi guru dapat membedakan kemampuan siswa satu dengan lainnya. Penilaian portofolio juga digunakan untuk mendorong peningkatan belajar para siswa. Dorongan peningkatan belajar dapat muncul dari siswa sendiri setelah mengetahui hasil penilaian itu, atau dapat juga diusahakan oleh guru yang telah memanfaatkan hasil penilaian itu untuk mengambil keputusan tentang pembelajaran siswanya.

Pembelajaran matematika dengan penilaian portofolio adalah pembelajaran dengan memperhatikan penilaian secara terus menerus, yakni meliputi: (1) Buku catatan 
siswa, (2) Lembar kerja siswa (LKS), (3) Quiz, (4) Tugas mandiri siswa, (5) Penilaian Afektif dan (6) Penilaian Psikomotorik. Hasil pekerjaan siswa tersebut didokumentasikan dan dimanfaatkan untuk melihat kemajuan belajarnya. Guru mengarahkan siswa untuk cermat dalam menyelesaikan tugas-tugas, agar siswa mau memperhatikan kesalahankesalahannya sekaligus memperbaiki kesalahan tersebut.

Penelitian yang dilakukan oleh Siti Chodijah (2012) menunjukkan bahwa model guided inquiry yang dilengkapi dengan penilaian portofolio memberikan hasil yang efektif yaitu rata-rata nilai peserta didik pada ranah kognitif 66.7, ranah afektif 61.2, ranah psikomotor adalah 68 dan rata-rata nilai persentase observasi efektivitas berdasarkan aktivitas peserta didik adalah $86,3 \%$. Kesamaan penelitian ini dengan penelitian di atas adalah pada penggunaan penilaian portofolionya, sedangkan perbedaannya adalah pada penelitian di atas digunakan model pembelajaran guided inquiry, pada penelian ini menggunakan model pembelajaran kooperatif tipe STAD.

Penelitian ini bertujuan untuk (a) menghasilkan perangkat pembelajaran pada model pembelajaran kooperatif tipe STAD dengan penilaian portofolio yang baik untuk pokok bahasan aljabar di kelas VII SMP, (b) untuk mengetahui apakah siswa yang diberi pembelajaran matematika dengan menggunakan kooperatif tipe STAD dengan penilaian portofolio mempunyai prestasi belajar yang lebih baik daripada siswa yang diberi pembelajaran matematika kooperatif tipe STAD tanpa portofolio, (c) untuk mengetahui apakah siswa yang mempunyai kemampuan awal tinggi mempunyai prestasi belajar yang lebih baik daripada siswa yang mempunyai kemampuan awal rendah, (d) untuk mengetahui apakah pada masing-masing tingkat kemampuan awal tinggi dan rendah, model pembelajaran kooperatif tipe STAD dengan penilaian portofolio akan menghasilkan prestasi belajar matematika siswa yang lebih baik dibandingkan dengan model pembelajaran kooperatif tipe STAD tanpa portofolio dan untuk mengetahui apakah pada masing-masing model pembelajaran tersebut siswa yang mempunyai kemampuan awal tinggi mempunyai prestasi belajar yang lebih baik dari pada siswa yang mempunyai kemampuan awal rendah.

\section{METODE PENELITIAN}

Penelitian ini merupakan penelitian pengembangan. Prosedur pengembangan yang digunakan dalam penelitian ini adalah pengembangan perangkat pembelajaran menurut Thiagarajan dkk (1974), yang terdiri dari empat tahap yaitu tahap pendefinisian (define), perancangan (design), pengembangan (develop), dan penyebaran (disseminate). Pada tahap pendefinisian (define), peneliti mendefinisikan permasalahan mendasar yang muncul dalam proses pembelajaran. Pada tahap perancangan (design), peneliti merancang 
perangkat pembelajaran yang terdiri dari Rencana Pelaksanaan Pembelajaran (RPP), Lembar Kerja Siswa (LKS), dan Tes Hasil Belajar (THB) yang menghasilkan Draf I. Kemudian pada tahap pengembangan, Draf I hasil dari rancangan awal divalidasi oleh para validator. Hasil validasi digunakan untuk merevisi Draf I sehingga menghasilkan Draf II. Draf II diujicobakan pada siswa kelas VII SMP Terpadu Ponorogo. Pada saat ujicoba diadakan pengamatan terhadap kemampuan guru dalam mengelola pembelajaran, aktivitas siswa juga diamati. Pada akhir pembelajaran, setiap siswa diminta untuk mengisi angket respon siswa. Sedangkan THB yang merupakan bagian dari perangkat pembelajaran yang dikembangkan juga dianalisis tentang validitas, reliabilitas dan tingkat kesukarannya. Hasil uji coba perangkat tersebut digunakan untuk merevisi Draf II sehingga menghasilkan Draf III yaitu perangkat pembelajaran yang baik. Buku siswa dan buku pegangan guru dibuat untuk memperlancar proses pembelajaran. Pada tahap develop dilakukan developmental testing berupa eksperimen terhadap model pembelajaran kooperatif tipe STAD dengan penilaian portofolio. Eksperimen dilakukan pada dua sekolah yaitu SMP Muhammadiyah Yanggong dan SMP Muhammadiyah Jenangan dengan mengambil satu kelas sebagai kelas ekperimen satu kelas lagi sebagai kelas kontrol. Teknik analisa data yang digunakan dalam eksperimen adalah analisis variansi dua jalan sel tak sama.

\section{HASIL PENELITIAN DAN PEMBAHASAN}

Hasil penelitian yang menggunakan model pengembangan 4D dapat dihasilkan perangkat pembelajaran model kooperatif tipe STAD dengan penilaian portofolio yang baik.

Dari hasil uji statistik dengan anava dua jalan, diperoleh $\mathrm{F}_{\mathrm{a}}=4.878>3.92=$ $\mathrm{F}_{0,05 ; 1 ; 120}$. Nilai $\mathrm{F}_{\mathrm{a}}$ terletak di daerah kritik maka $\mathrm{H}_{\mathrm{oA}}$ ditolak berarti model pembelajaran berpengaruh terhadap prestasi belajar pada aljabar. Dari rataan marginalnya $\left(\bar{x}_{1}=66.355\right.$ > $63.597=\bar{x}_{2}$ ) menunjukkan bahwa pembelajaran dengan model pembelajaran kooperatif tipe STAD dengan penilaian portofolio menghasilkan prestasi belajar matematika yang lebih baik dibandingkan model pembelajaran kooperatif tipe STAD tanpa penilaian portofolio pada materi aljabar.

Berdasarkan hasil penelitian, pada hipotesis kedua bahwa model pembelajaran kooperatif tipe STAD dengan penilaian portofolio menghasilkan prestasi belajar matematika lebih baik dibandingkan pembelajaran kooperatif tipe STAD tanpa portofolio.

Hasil penelitian ini sesuai dengan teori Stiggins (1991:20) yaitu portofolio selain sangat bermanfaat dalam memberikan informasi mengenai kemampuan dan pemahaman 
peserta didik serta memberikan gambaran mengenai sikap dan minat peserta didik terhadap pelajaran yang diberikan, juga dapat menunjukkan pencapaian atau peningkatan yang diperoleh peserta didik dari proses pembelajaran.

Hasil penelitian juga sesuai dengan penelitian yang dilakukan oleh Tri Suwarni Widayati (2009) berjudul Efektivitas Model Pembelajaran Portofolio terhadap Hasil Belajar Matematika Ditinjau dari Sikap Siswa terhadap Matematika kelas XI IPS SMA Negeri Di Kabupaten Klaten Tahun Ajaran 2008/2009, dengan hasil penelitian menunjukkan bahwa hasil belajar matematika yang menggunakan model pembelajaran portofolio lebih baik dibandingkan dengan model pembelajaran konvensional baik secara umum maupun jika ditinjau dari masing-masing sikap.

Dari hasil analisis variansi diperoleh $\mathrm{F}_{\mathrm{b}}=53.658$ lebih besar dari $\mathrm{F}_{\text {tabel }}=3.92$ makan $\mathrm{H}_{0 \mathrm{~B}}$ ditolak. Sehingga diperoleh kesimpulan bahwa terdapat perbedaan prestasi belajar siswa dengan kemampuan awal tinggi dan rendah pada pokok bahasan aljabar. Dari rataan marginalnya $\left(\bar{x}_{1}=68.908>60.644=\bar{x}_{2}\right)$ menunjukkan bahwa prestasi belajar siswa yang mempunyai kemampuan awal tinggi lebih baik dari pada prestasi belajar siswa yang mempunyai kemampuan awal rendah pada materi aljabar.

Dari hasil penelitian ini diperoleh hasil sesuai dengan hipotesis ketiga bahwa prestasi belajar matematika siswa yang mempunyai kemampuan awal tinggi lebih baik jika dibandingkan dengan siswa yang mempunyai kemampuan awal rendah.

Hasil penelitian sesuai dengan Driscoll (dalam Yusak Sugiarto, 2009:27) bahwa "Kemampuan awal adalah kemampuan-kemampuan yang sudah dikuasai sebelum proses pembelajaran pokok tertentu dimulai, mengaktifkan kemampuan awal yang relevan merupakan hal sangat penting untuk menghasilkan belajar yang bermakna, dengan adanya kemampuan awal merupakan penyediaan landasan dalam belajar hal-hal baru”.

Hasil penelitian sesuai dengan penelitian yang dilakukan oleh Sriwahyuningsih (2010) dengan judul tesis "Pembelajaran Fisika dengan Metode Eksperimen dan Demonstrasi ditinjau dari Kemampuan Awal dan Sikap Ilmiah Siswa” yang memberikan hasil bahwa terdapat perbedaan prestasi belajar fisika antara siswa yang memiliki kemampuan awal tinggi dan rendah.

Dari hasil analisis variansi diperoleh pula $\mathrm{F}_{\mathrm{ab}}=7.14104$ lebih besar dari $\mathrm{F}_{\text {tabel }}=$ 3.92 maka $\mathrm{H}_{0 \mathrm{AB}}$ ditolak. Sehingga diperoleh kesimpulan bahwa ada interaksi antara kemampuan awal dan model pembelajaran terhadap prestasi belajar. Hal ini sesuai dengan hasil penelitian yang dilakukan oleh Rohani (2011) yang menunjukkan adanya interaksi antara model pembelajaran dengan kemampuan awal dalam mempengaruhi hasil belajar PKN siswa yaitu diperoleh $\mathrm{F}_{\text {hitung }}=7.479>\mathrm{F}_{\text {tabel }}=2.761$. 
$\mathrm{H}_{0 \mathrm{AB}}$ ditolak maka perlu dilakukan uji komparasi ganda antar sel pada kolom maupun pada baris yang sama dengan metode Scheffe'. Diperoleh keputusan uji bahwa $\mathrm{F}_{11-21}>\mathrm{F}_{\text {tabel }}, \mathrm{F}_{12-22}<\mathrm{F}_{\text {tabel }}$ dari hasil ini dapat disimpulkan sebagai berikut: Pada kemampuan awal tinggi, model pembelajaran kooperatif tipe STAD dengan penilaian portofolio lebih efektif dari pada pembelajaran dengan model pembelajaran kooperatif tipe STAD. Hasil ini sesuai dengan hipotesis penelitian bahwa pembelajaran dengan model pembelajaran kooperatif tipe STAD dengan penilaian portofolio menghasilkan prestasi belajar matematika siswa yang lebih baik dengan pembelajaran yang menggunakan model pembelajaran kooperatif tipe STAD tanpa penilaian portofolio pada siswa dengan kemampuan awal tinggi, Pada kemampuan awal rendah, model pembelajaran kooperatif tipe STAD dengan penilaian portofolio sama efektifnya dengan model pembelajaran dengan kooperatif tipe STAD. Hasil penelitian tidak sesuai dengan hipotesis penelitian bahwa pembelajaran dengan model pembelajaran kooperatif tipe STAD dengan penilaian portofolio menghasilkan prestasi belajar matematika siswa yang lebih baik dengan pembelajaran yang menggunakan model pembelajaran kooperatif tipe STAD tanpa penilaian portofolio pada siswa pada kemampuan awal rendah.

Berdasarkan keputusan uji bahwa $\mathrm{F}_{11-12}>\mathrm{F}_{\text {tabel }}, \mathrm{F}_{21-22}>\mathrm{F}_{\text {tabel }}$ dari hasil ini dapat disimpulkan sebagai berikut: Pada siswa yang menggunakan model pembelajaran dengan model pembelajaran kooperatif tipe STAD dengan penilaian portofolio, siswa berkemampuan awal tinggi mempunyai prestasi lebih baik dari pada siswa berkemampuan rendah. Hasil ini sesuai dengan hipotesis penelitian bahwa pada masingmasing model pembelajaran dengan penilaian portofolio dan tanpa portofolio, siswa dengan kemampuan awal tinggi mempunyai prestasi belajar yang lebih baik daripada siswa dengan kemampuan awal rendah. Pada siswa yang menggunakan model pembelajaran dengan kooperatif tipe STAD, siswa berkemampuan awal tinggi mempunyai prestasi lebih baik dari pada siswa berkemampuan awal rendah. Hasil ini sesuai dengan hipotesis penelitian bahwa pada masing-masing model pembelajaran dengan penilaian portofolio dan tanpa portofolio, siswa dengan kemampuan awal tinggi mempunyai prestasi belajar yang lebih baik daripada siswa dengan kemampuan awal rendah.

\section{SIMPULAN DAN SARAN}

Berdasarkan uraian di atas, dapat disimpulkan beberapa hal berikut. Perangkat pembelajaran kooperatif tipe STAD dengan penilaian portofolio untuk pokok bahasan aljabar dikembangkan dengan menggunakan model pengembangan 4-D yang dimodifikasi. Pengembangan perangkat pembelajaran dengan model ini terdiri dari 4 
tahap yaitu: pendefinisian (define), perancangan (design), pengembangan (develop) dan penyebaran (disseminate). Dengan menggunakan model ini, dihasilkan perangkat pembelajaran yang valid untuk pokok bahasan aljabar yang mengacu pada model pembelajaran kooperatif tipe STAD dengan penilaian portofolio. Perangkat pembelajaran yang dihasilkan meliputi: (1) Rencana Pelaksanaan Pembelajaran (RPP), (2) Buku Pegangan Guru (BPG), (3) Buku Siswa, (4) Lembar Kerja Siswa (LKS) dan (5) Tes Hasil Belajar (THB). Berdasarkan analisis inferensial diperoleh bahwa prestasi belajar matematika siswa yang mengikuti pembelajaran kooperatif tipe STAD dengan penilaian portofolio lebih baik dibandingkan dengan prestasi belajar matematika siswa yang mengikuti pembelajaran kooperatif tipe STAD untuk pokok bahasan aljabar kelas VII SMP Muhammadiyah di kabupaten Ponorogo. Prestasi belajar matematika siswa yang mempunyai kemampuan awal tinggi lebih baik daripada prestasi belajar siswa yang mempunyai kemampuan awal rendah pada materi aljabar. Pada kemampuan awal tinggi, siswa yang diajar dengan menggunakan model pembelajaran kooperatif tipe STAD dengan penilaian portofolio mempunyai prestasi belajar lebih baik dari pada pembelajaran dengan model pembelajaran kooperatif tipe STAD. Pada kemampuan awal rendah, siswa yang diajar dengan menggunakan model pembelajaran kooperatif tipe STAD dengan penilaian portofolio mempunyai prestasi sama dengan model pembelajaran dengan kooperatif tipe STAD. Pada siswa yang menggunakan model pembelajaran dengan kooperatif tipe STAD, siswa berkemampuan awal tinggi mempunyai prestasi lebih baik dari pada siswa berkemampuan awal rendah. Pada siswa yang menggunakan model pembelajaran kooperatif tipe STAD dengan penilaian portofolio, siswa berkemampuan awal tinggi mempunyai prestasi lebih baik dari pada siswa berkemampuan rendah.

\section{DAFTAR PUSTAKA}

Burhanudin Tola dan Fahmi. 2003. Standar Penilaian di Kelas. Jakarta: Departemen Agama RI.

Deckey and Adam. 1995. Basic Principles of Student Teaching. New Jersey: Prentice Hall, Inc.

Hafis Muaddab. 2011. Jaminan Mutu dalam Sertifikasi Guru. Diakses dari (http://netsains.com/2011/10/jaminan-mutu-dalam-sertifikasi-guru/) pada tanggal 18 Oktober 2011.

Irma Pujianti. 2008. Peningkatan Motivasi dan Ketuntasan Belajar Matematika melalui Pembelajaran Kooperatif Tipe STAD. Khasanah Pendidikan. vol. 1, no. 1 page 70-91. 
Popham, W.J. 2001. Teaching to The Test. Educational Leadership, 58 (6), 16-20.

Rohani. 2011. Pengaruh Model Pembelajaran Berbasis Portofolio dan Kemampuan Awal terhadap Hasil Belajar Pendidikan Kewarganegaraan Siswa Madrasah Aliyah Laboratorium IAIN SU Medan.

Siti Chodijah. 2012. Pengembangan Perangkat Pembelajaran Fisika Menggunakan Model Guided Inquiry yang Dilengkapi Penilaian Portofolio pada Materi Gerak Melingkar. Jurnal Penelitian Pembelajaran Fisika I (2012). ISSN : 2252-3014 page 1-19.

Slavin, R.E. 1992. Cooperative Learning. USA: Allyn and Bacon.

Sri Wahyuningsih. 2010. Pembelajaran Fisika dengan Metode Eksperimen dan Demonstrasi Ditinjau dari Kemampuan Awal dan Sikap Ilmiah Siswa.Tesis. Program Pasca Sarjana Universitas Sebelas Maret Surakarta.

Stiggins, RJ. 1991. Student-Centered Classroom Assessment. New York: Mac Milan Cottage, Publishing Company.

Sumarna Supranata dan Muhammad Hatta. 2004. Penilaian Portofolio:Implementasi Kurikulum 2004. Bandung: PT. Remaja Rosdakarya.

Tri Suwarni Widayati. 2009. Efektivitas Model Pembelajaran Portofolio terhadap Hasil Belajar Matematika Ditinjau dari Sikap Siswa terhadap Matematika kelas XI IPS SMA Negeri Di Kabupaten Klaten Tahun Ajaran 2008/2009. ThesisMagister, tidak diterbitkan. UNS, Surakarta 